\title{
Posterior polymorphous corneal dystrophy
}

INSERM

\section{Source}

INSERM. (1999). Orphanet: an online rare disease and orphan drug data base. Posterior polymorphous corneal dystrophy. ORPHA:98973

Posterior polymorphous corneal dystrophy (PPCD) is a rare mild subtype of posterior corneal dystrophy (see this term) characterized by small aggregates of apparent vesicles bordered by a gray haze at the level of Descemet membrane, generally with no effect on vision. 